\title{
Development Stages of Franchising Relations in Civil Law Relations in Kazakh Law
}

\author{
Okutman, Galia ASSIL'BEKOVA *
}

\begin{abstract}
:
In this paper I dealt the history and establishment process of relations of contract of package entrepreneurial license (franchising). I also discussed concept and attributes of contract of package entrepreneurial license (franchising). I showed the types of contract of package entrepreneurial license (franchising).

Key words: Franchising contracts, Kazakhstan law, the history of franchising, types of franchising.
\end{abstract}

\section{Kazak Hukukunda Medeni Hukuk Münasebetlerinde Françayzingin Gelişme Merhaleleri}

\section{Özet:}

$\mathrm{Bu}$ makalede, Kazakistan hukukunda françayz(ing) (imtiyaz verme) sözleşmelerinin tarihini ve kurulmasını ele aldım. Aynı zamanda, françayz sözleşmeleri kavramını ve bu sözleşmelerin niteliklerini müzakere edip türlerini gösterdim.

Anahtar Kelimeler: Françayz sözleşmeleri, françayz sözleşmelerinin tarihi ve türleri, Kazakistan hukuku

M. Utemişov Adına Batı Kazakistan Devlet Üniversitesi, / Asilbekova.Galiya@Mail.Ru 


\section{$342 \cdot$ YALOVA SOSYAL BILIMLER DERGISI}

Franchising is the form of long-term business relations, several advantages offered by the franchising relations to its participants are as follows:

1. It offers and provides the beginning entrepreneur with opportunities to arrange own business activities through the use of profitable evenkeeled business;

2. It's the way of expansion and strengthening the activities of the famous company in the market;

3. It is the beneficial method of the Government in supporting the entrepreneurship [Nazarbayev, 2008, s. 1].

Under the franchise agreement, we understand the relationship of agreement, giving license to use the methods of business, and the realization of separate licensor's business transactions on behalf of the licensor. Typically, a franchising agreement with the licensor makes it possible to closely monitor business activity during the term of the license [Law of the Republic of Kazakhstan: "About complex business license (franchising)"].

Franchise agreements are used in various fields. Issuance of licenses by owners of trademarks and patents, intellectual property, and other objects to others is often used abroad. That is, franchising is one of the most popular international legal institutions.

The process of developing of franchise system consists of the following five steps:

1. Determinate sides participating in the development stage of franchising concept, establish their duties;

2. Identify the participants at the development stage of franchising concept, establish rules and conditions;

3. Mastermind the methodical instructions;

4. Make up a plan to expand the system at the development stage of franchising program;

YIL: 5 SAYI: 10 
5. Implementation and control of this program [Zhailin, 2006, $2^{\text {nd }}$ part]

According to the Association of franchising in Kazakhstan, our country has 450 franchise systems and over 3,000 franchise companies.

After studying the formation and development of franchising in Kazakhstan, it was determined that some domestic enterprises have declared themselves as social franchisors. (Table)

\section{Description of services of companies in the field of franchising in Kazakhstan}

\begin{tabular}{|l|l|l|}
\hline Type of franchising & Description of services & Name of company \\
\hline Service & Fast food places & "Pizza Hot", "Kanagat" \\
\hline Trading & Food stores & "Ramstore", "Skif" \\
\hline Trading & Retail sale of clothing & $\begin{array}{l}\text { "Max Mara", } \\
\text { "Sela", } \\
\text { "Mango" }\end{array}$ \\
\hline Master of franchisee & $\begin{array}{l}\text { Telecommunications and } \\
\text { communication facilities }\end{array}$ & "Kazakhtele c o m", \\
\hline Trading & Chemist's shops & "Emity", "Romat" \\
\hline Master of franchisee & Transport companies & "Transsystema" \\
\hline Service & Restaurants & "Intercontinental" \\
\hline Master of franchisee & Beauty salons & "Nails Club" \\
\hline
\end{tabular}

The aim of franchising is to spread the consumer goods (own goods, works and services) and to distribute the means of production.

On this basis it is possible to distinguish between types of franchising. 
$344 \cdot$ YALOVA SOSYAL BILIMLER DERGISI

1. Franchising - licensor grants to licensee the workplace and the license complex with capabilities of private businessman;

2. The enterprise franchising - licensor grants to licensee the enterprise with license complex;

3. The conversion franchising - defines the conditions of sides on the basis of restructuring of structural units of the private enterprises;

4. The increased franchising - the licensee is building several companies;

5. The manufacturing franchising - a comprehensive licensor gives the right to the licensee with licensor's consent to use raw materials, technologies and equipment for distribution of its trademark, to carry out a production and sale of goods and services;

6. The trade franchising - comprehensive licensor gives the right to the licensee to use the marketing technologies, given by the comprehensive licensor and specified in the contract, and to sell goods, works and services on their trademark [Schmittoff, 2012, s. 34].

For example, focus on the development stages of franchising in Kazakhstan:

The first period: Companies that have appeared in the period of 19941999s: "Coca Cola", "Rahat Palace" in 1994, "Adidas" in 1995, "Seymar" in 1996, "KODAK" in 1997, "Doca", "Ankara", "Ramstore" in 1999.

Key Features:

1. Lack of regulatory framework, establishing a franchise

2. Lack of competition in the market

3. Exit to the Kazakhstan market in order to expand the sphere of influence of private foreign companies

4. Beginning of the formation of industrial and service franchising

The second period: Companies that have appeared during the period of 2000-2004s:

YIL: 5 SAYI: 10 
"Baskin Robbins" in 2000, Franchise Association of Kazakhstan, the Law of the Republic of Kazakhstan "About complex business license (franchising)", "II Patio", "Sushi Planet", "World Class" in 2002, "Business Consult", "Scot Holland Estates", "Pyaterochka", "MaxMara", "Sela", "Three Fat Men" in 2004.

Key Features:

1. The law about franchising was passed

2. The competition associated with market entry of large foreign firms franchisee took shaped

3. A Franchise Association of Kazakhstan was created

4. Franchising in the direction of the development and using of USAID business

The third period: Company, existing since 2005:

"English First", “Alma - TV”, "Tiffany Marble" in 2005, "Romat", "Umex Realty" in 2006, "Finn Flare" in 2007, "Aquatoria of Luxury Life" in 2008.

Key Features:

1. The active using of the law on intellectual property and franchising

2. The exhibition of franchising was organized

3. Small Business Development Fund has developed a lending program of franchising

4. Competition is developing rapidly

5. The media and social franchising has been appeared

The openness of the country and the expansion of international integration exert their influence on the development of this type of business in Kazakhstan. However, most entrepreneurs believe that they are free from paying taxes. In our country, in general, the amount of taxes is not higher than in other countries. In my opinion, low prevalence and the small credibility to franchising effect on its rapid development. Now in 
our country $80 \%$ of trade is franchising. This is not a professional franchise [Seitzhanuly, s. 16].

In the US a franchise business works out 30 trillion dollars. This was reported on "Franchising in Kazakhstan" the $2^{\mathrm{d}}$ International Forum held in Almaty by the US Embassy in Kazakhstan. "For the state a franchise is economic growth. Franchise companies will contribute to the economic growth of the country. So, thanks to the franchise, 11 million workplaces were opened in the United States, $\$ 2.8$ billion are used to paying out salaries for employees. Also the opening of new workplaces will be increased by $10-15 \%$ due to franchising. In recent years, the franchise business is growing rapidly every year. This is the highest growth in all fields of the country", said the US ambassador. According to him, the franchise will play an important role in Kazakhstan. Thus, franchising was founded in 1973 in Egypt. 4 years later, the Egyptian investors began to build new plants for the development of the restaurant business and in direction of the preparation of food (potatoes, etc.). And after that, in order to glorify his kitchen in the world, they adopted the best practices of Western countries and rapidly developed this business.

Coca-Cola, Baskin Robbins, MacDonald's, World Class are the world famous franchisors. These companies have become known to the world with the help of franchising. According to the international press, the annual turnover of the franchise in the world is $\$ 2$ trillion US dollars. A franchising powers volume has reached 2 million.

Franchising is widespread in Western countries. Because entrepreneurs consider it as a guarantee of success of any business initiative. To what extent is the trend of the business developed in Kazakhstan? For the first time the term "franchise agreement" was used in the Civil Code in 1999. In 2002, a special law on franchising was passed. In Central Asia, now Kazakhstan has begun his career in the field of franchising. It is proved that every year in our country, a number of franchise systems is growing.

YIL: 5 SAYI: 10 
According to the statistics agency, today in Kazakhstan foreign franchise systems can be classified in several fields of business development. These are: retail trade $(60 \%)$, services $(30 \%)$, catering $(3 \%)$, production sphere (7\%), and among consumer goods is an active sale of clothing and shoes of famous foreign brands.

In our country such franchise systems as Coca-Cola, Baskin Robbins, World Class, British Airways and "Perekrestok" are successfully developed. Hotel business began in 1994. It must be said about the "Rahat Palace" and "Ankara" as part of the international hotels of Hyatt Regency franchise brand. Now they are part of the "Intercontinental" famous hotels. In the restaurant business, you can give the example of a "Rosinter" Russian company, took his place in the Kazakhstan market. This company in our country is known for its brands "El Patio", "Sushi Planet”, "American Bar and Grill”, "Moka-Loka", etc.

Looking at the global statistics, we conclude that upon expiry of 5 years among independently discovered 100 companies only 10 have continued their work. For over 5 years $90 \%$ of enterprises, being contractors, have being remained in the market.

Summing up about consideration of civil legal relations, comparing working in our country franchising companies with economic entities in other businesses, I must say that they have significant features and benefits. According to this, we believe that under present conditions it is possible to quickly solve problems associated with this system of business, develop small and medium-sized businesses and achieve positive results.

According to the Message of the President of the Republic of Kazakhstan in 2008, within the program to support domestic producers, the number of workplaces is expanding in our country due to the law about the conditions of the franchise agreement and an increase in the number of domestic franchisors, able to compete in the local and international market. 
$348 \cdot$ YALOVA SOSYAL BILIMLER DERGISI

\section{References:}

Nazarbayev Nursultan, "The main goal of public policy to improve the material prosperity of Kazakhstan people." in Independent Kazakhstan, 2008

Law of the Republic of Kazakhstan "About complex business license (franchising)", in Sovereign Kazakhstan, 04.07.2002

Zhailin G. A., Civil law. Special section, the $2^{\mathrm{d}}$ part, 2006

Schmittoff K. M., The law and practice of international trade, Sweet \& Maxwell; 12th Revised edition (25 Sept. 2012), London, s. 34

Seitzhanuly Beknur, "Franchising in Kazakhstan", s. 16 